\title{
Factors Related to the Unmet Need for Family Planning in Married Women of Childbearing Age in West Nusa Tenggara Province
}

\author{
$* 1^{\text {st }}$ Aulia Amini \\ Departement of Midwifery \\ Universitas Muhammadiyah Mataram \\ Mataram, Indonesia \\ auliaamini1406@gmail.com
}

\author{
$2^{\text {nd }}$ Indriyani Makmun \\ Departement of Midwifery \\ Universitas Muhammadiyah Mataram \\ Mataram, Indonesia \\ ndry.ani88@gmail.com \\ $4^{\text {th }}$ Catur Esty Pamungkas \\ Departement of Midwifery \\ Universitas Muhammadiyah Mataram \\ Mataram, Indonesia \\ catur.esty@gmail.com
}

\author{
$3^{\text {rd }}$ Ana Pujianti Harahap \\ Departement of Midwifery \\ Universitas Muhammadiyah Mataram \\ Mataram, Indonesia \\ ana.harahap87@gmail.com
}

\begin{abstract}
Based on the data from Demographic and Health Survey 2017, family planning unmet needs in married women aged $15-49$ as much as $11 \%$. The proportion of unmet need in Indonesia is not in line with the case of unmet need in West Nusa Tenggara province which is equal to $15.6 \%$. The aim of this research is to determine the factors associated with the incidence of unmet need for family planning in married women of childbearing age in West Nusa Tenggara. This research uses cross-sectional study design. The study also uses secondary data from the Demographic and Health Survey of 2017. The population in the study is entire married women of childbearing aged 15-49 in West Nusa Tenggara. The sample in this study aged 15-49 years that established by level and sample as many as 498 samples. Sampling method of this study is multistage stratified sampling. The research variables include independent variables which are age, parity, education, knowledge, access to health care, area of residence, and income, and including the dependent variable which is the case of unmet need. Analysis of data using univariate and bivariate analysis with chi square test with $95 \%$ confidence level. Characteristics identification of women of childbearing age in West Nusa Tenggara province obtained a no-risk age category $(\mathbf{7 0 . 1 \%})$, not at risk $(95.6 \%)$, secondary education $(54.4 \%)$, gain easy access to health services $(63.3 \%)$, had knowledge of the use of any contraceptive $(64.5 \%)$, most of women of childbearing age in urban areas $(51 \%)$, and are on a low income level $(31.1 \%)$. There was a significant correlation between the case of unmet need knowledge with family planning on married women of childbearing age in West Nusa Tenggara $(0.000>0.05)$. There is no significant relationship between age, parity, education, access to health services, residential areas and income with the unmet need for family planning in married women of childbearing age in West Nusa Tenggara Province.
\end{abstract}

Keywords - unmet need, family planning, married women, childbearing age

\section{INTRODUCTION}

Family Planning according to the World Health Organization (WHO) is an action that helps married couples to avoid unwanted births, get a birth that are desired, set the interval between births, birth control and determine the number of children in the family. The general aim of family planning programs towards smaller families in accordance with the socio-economic power by child's birth control is in order to obtain a happy and prosperous family that can meet their needs[1]. The population continues to increase is a major problem for the countries in the world especially in developing countries. Indonesia is the country with the fourth largest population after China, India and the United States [2]. Unmet need is a need for contraceptives that are not met. Women of childbearing age is said to be an unmet need if they want to delay pregnancy or terminate a pregnancy for the next two years but are not using contraception[3]. This group is the target that needs serious attention in view of those who are still in need of family planning services but has not been met, resulting in the tendency of unwanted pregnancy[4]. Experience of contraceptive failure, the last child's age, and the age of couples of reproductive ages as a reference. in the choice of contraception. Meanwhile, on the other hand, available contraceptives do not fit exactly as desired. These conditions lead to trouble pressing unmet need[5]. One indicator of the success of family planning programs, both in Indonesia and global level, is to fulfill the needs of contraception[6]. The high number of meeting unmet need affects the spacing and number of children born to high risk of maternal and infant mortality[7]. A study showed that there are differences in the level of unmet need for family planning between urban and rural areas. This is due to the characteristics of women in urban and rural areas are not too different[5].

The success of family planning programs, one of which, seen from the decline in the total fertility rate from 2.6 in 2012 to 2.4 in 2017 . The TFR decline was followed by a decrease in unmet need family planning means that in 2012 amounted to 11.4 to 10.62017 , however, the proportion of unmet need in Indonesia is not in line with the occurrence of unmet need in West Nusa Tenggara Province which is $15.6 \%[3]$. Based on the results of the Democratic Health Survey Indonesia (IDHS) in 2017, West Nusa Tenggara with the proportion of married women want family planning by 
$16 \%$, has been using family planning by $52 \%$ and the unmet needs of family planning (unmet need) by $38 \%$. On the results of 2017 IDHS, West Nusa Tenggara province can be seen that the incidence of unmet need is still high compared with the national Demographic and Health Survey results and has not been resolved in accordance KKBPK program objectives. According to a characteristic pattern (married women), the percentage of married women with family planning needs are unmet highest in the age group 45-49 $(20 \%)$, family planning needs are unmet among married women by $17 \%$ compared to $15 \%$ women in rural areas and the need for family planning among married women is not much different by level of education and wealth quintile[3]. Factors affecting the high number of unmet needs among others because of age, number of children, social, economic, education, science, health care, the cost of contraception, husband support and health status[8]. Improvements to the provision of counseling services centered on client needs and preferences of family planning methods, and the provision of affordable services to anyone in need is the most important component to support reducing maternal mortality[9]. The purpose of this study was to determine the factors associated with the case of unmet need for family planning in West Nusa Tenggara.that follow.

\section{METHOD}

The design used in this study is an observational design (cross-sectional). This study provides an overview of the factors that influence the occurrence of unmet need in married childbearing age women. This study was an analytical study using secondary data research results IDHS 2017. The study was conducted in the province of West Nusa Tenggara using data from Demographic and Health Survey 2017. The population in this study were all aged 15-49 married childbearing age women in West Nusa Tenggara province, in ten districts or town and has equal representation between urban and rural areas. Total population which has been determined as 1400 samples of households consisting of 700 samples of urban households and rural households 700 samples from IDHS report West Nusa Tenggara Province. The sample in this study aged 15-49 years married childbearing age women in West Nusa Tenggara. The sample size used in this study are adjusted for the married childbearing age women established by level and sample as 498 samples. Mechanical sampling carried out by multistage stratified sampling. The variables of this study include independent variables which are age, parity, education, knowledge, access to health care, area of residence, and income, and the dependent variable which is the incidence of unmet need. Materials and research instruments used to measure each variable using the tools of a questionnaire with structured questions used during the 2017 Demographic and Health Survey conducted in depth. Analysis of data using a data analysis of univariate and bivariate analysis using chisquare test with $95 \%$ confidence level.

\section{RESULT}

\section{A. Characteristics of research subjects}

TABLE I. THE FREQUENCY DISTRIBUTION OF AGE, PARITY, EDUCATION, KNOWLEDGE, ACCESS TO HEALTH CARE, AREA OF RESIDENCE, AND INCOME ON MARRIED CHILDBEARING AGE WOMEN IN THE PROVINCE OF WEST NUSA TENGGARA.

\begin{tabular}{|c|c|c|c|c|}
\hline \multirow[t]{2}{*}{ No. } & Variables & $\mathbf{N}$ & 0 & \multirow{2}{*}{ Mean } \\
\hline & Age & & $\%$ & \\
\hline 1 & At risk & 149 & 29.9 & \multirow{3}{*}{1.7} \\
\hline 2 & Not at risk & 349 & 70.1 & \\
\hline Total & & 498 & 100 & \\
\hline No. & Parity & & & \multirow{4}{*}{1.96} \\
\hline 1 & At risk & 22 & 4.4 & \\
\hline 2 & Not at risk & 476 & 95.6 & \\
\hline Total & & 498 & 100 & \\
\hline No. & Education & & & \multirow{6}{*}{1.88} \\
\hline 1 & Unschooled & 14 & 2.8 & \\
\hline 2 & Elementary & 123 & 24.7 & \\
\hline 3 & Secondary & 271 & 54.4 & \\
\hline 4 & High & 90 & 18.1 & \\
\hline Total & & 498 & 100 & \\
\hline No. & \multicolumn{4}{|c|}{ Knowledge of married childbearing age women } \\
\hline 1 & Do not know & 177 & 35.5 & \multirow{3}{*}{1.64} \\
\hline 2 & Know & 321 & 64.5 & \\
\hline Total & & 498 & 100 & \\
\hline No. & \multicolumn{4}{|c|}{ Access to health services } \\
\hline 1 & Not easy & 183 & 36.7 & \multirow{3}{*}{0.63} \\
\hline 2 & Easy & 315 & 63.3 & \\
\hline Total & & 498 & 100 & \\
\hline No. & Area of residen & & & \multirow{4}{*}{1.49} \\
\hline 1 & City & 254 & 51 & \\
\hline 2 & Village & 244 & 49 & \\
\hline Total & & 498 & 100 & \\
\hline No. & Income & & & \multirow{7}{*}{2.53} \\
\hline 1 & Extremely poor & 155 & 31.1 & \\
\hline 2 & Poor & 114 & 22.9 & \\
\hline 3 & Middle & 105 & 21.1 & \\
\hline 4 & Rich & 60 & 12.0 & \\
\hline 5 & Very rich & 64 & 12.9 & \\
\hline Total & & 498 & 100 & \\
\hline No. & Unmet need & & & \multirow{4}{*}{1.65} \\
\hline 1 & Unmet need & 176 & 35.3 & \\
\hline 2 & Not unmet need & 322 & 64.7 & \\
\hline Total & & 498 & 100 & \\
\hline
\end{tabular}

Table 1 shows that most of the married childbearing age women is not at risk (20-35 years) as many as 349 samples $(70.1 \%)$. Parity on married childbearing age women mostly not at risk (the number of children $\leqslant 4$ ) that as many as 476 samples $(95.6 \%)$. Most of married childbearing age women education at the level of secondary education as many as 271 samples $(54.4 \%)$. The average level of knowledge of at least one type of tool contraceptives as many as 1.64 in 321 people (64.5\%) Married childbearing age women in West Nusa Tenggara. Married childbearing age women who gain access to health care facilities in as many as 315 people $(63.3 \%)$. Most WUS live in the city as many as 254 people $(51 \%)$, and most of the income level of WUS included into the category of very poor as many as 155 people $(31.1 \%)$. As many as 322 people (64.7\%) WUS using one of the contraceptives, and not including the unmet need for family planning. 
B. Relationship of age factor, parity factor, educational, knowledge, access to health service, recidential areas, and income factor with the incidence of unmet need in family planning of married childbearing age women in West Nusa Tenggara

TABLE II. RELATIONSHIP OF AGE FACTOR, PARITY FACTOR, EDUCATIONAL, KNOWLEDGE, ACCESS TO HEALTH SERVICE, RECIDENTIAL AREAS, AND INCOME FACTOR WITH THE INCIDENCE OF UNMET NEED IN FAMILY PLANNING OF MARRIED CHILDBEARING AGE WOMEN IN WEST NUSA TENGGARA

\begin{tabular}{|c|c|c|c|c|c|c|c|}
\hline \multirow{3}{*}{ Variables } & \multicolumn{4}{|c|}{$\begin{array}{l}\text { Genesis unmet need for family } \\
\text { planning }\end{array}$} & \multirow{2}{*}{\multicolumn{2}{|c|}{ Total }} & \multirow{3}{*}{$P$} \\
\hline & \multicolumn{2}{|c|}{ Unmet need } & \multicolumn{2}{|c|}{$\begin{array}{c}\text { Not unmet } \\
\text { need }\end{array}$} & & & \\
\hline & $\mathbf{N}$ & $\%$ & $\mathbf{N}$ & $\%$ & $\mathbf{N}$ & $\%$ & \\
\hline \multicolumn{8}{|l|}{ Age } \\
\hline At risk & 49 & 27.8 & 100 & 31.1 & 149 & 29.9 & \multirow{3}{*}{0.454} \\
\hline Not at risk & 127 & 72.2 & 222 & 68.9 & 349 & 70.1 & \\
\hline \multicolumn{7}{|l|}{ Parity } & \\
\hline At risk & 4 & 2.3 & 18 & 5.6 & 22 & 4.4 & \multirow{2}{*}{0,085} \\
\hline Not at risk & 172 & 97.7 & 304 & 94.4 & 476 & 95.6 & \\
\hline \multicolumn{8}{|l|}{ Education } \\
\hline Uneducated & 4 & 2.3 & 10 & 3.1 & 14 & 2.8 & \multirow{4}{*}{0.908} \\
\hline Elementary & 45 & 25.6 & 78 & 24.2 & 123 & 24.7 & \\
\hline Secondary & 97 & 55.1 & 174 & 54.0 & 271 & 54.4 & \\
\hline High & 30 & 17.0 & 60 & 18.6 & 90 & 18.1 & \\
\hline \multicolumn{8}{|l|}{ Knowledge } \\
\hline Do not know & 176 & 100 & 1 & 0.3 & 177 & 35.5 & \multirow[b]{2}{*}{0,000} \\
\hline Know & 0 & 0 & 321 & 99.7 & 321 & 64.5 & \\
\hline \multicolumn{8}{|c|}{ Access to health services } \\
\hline Not easy & 68 & 38.6 & 115 & 35.7 & 183 & 36.7 & \multirow{2}{*}{0.518} \\
\hline Easy & 108 & 61.4 & 207 & 64.3 & 315 & 63.3 & \\
\hline \multicolumn{8}{|c|}{ Residential areas } \\
\hline City & 97 & 55.1 & 157 & 48.8 & 254 & 51.0 & \multirow{2}{*}{0.175} \\
\hline Village & 79 & 44.9 & 165 & 51.2 & 244 & 49.0 & \\
\hline \multicolumn{8}{|l|}{ Income } \\
\hline $\begin{array}{l}\text { Extremely } \\
\text { poor }\end{array}$ & 53 & 30.1 & 102 & 31.7 & 155 & 31.1 & \multirow{5}{*}{0.774} \\
\hline Poor & 44 & 25.0 & 70 & 21.7 & 114 & 22.9 & \\
\hline Middle & 40 & 22.7 & 65 & 20.2 & 105 & 21.1 & \\
\hline Rich & 19 & 10.8 & 41 & 12.7 & 60 & 12.0 & \\
\hline Very rich & 20 & 11.4 & 44 & 13.7 & 64 & 12.9 & \\
\hline
\end{tabular}

Based on table 2 is known that non-risk age group (20-35 years) largely unmet need as many as 222 people $(68.9 \%)$ and obtained as many as 49 people at-risk age $(<20$ years and $>35$ years) included in unmet need for family planning. When viewed from the $p$ value $p=0.454$ with $\alpha=0.05$, it can be concluded that there is no significant relationship between the age group with the incidence of unmet need for family planning in the married childbearing age women of West Nusa Tenggara in $2017(p>\alpha)$. The married childbearing age women who have less than 4 children (no risk) is an unmet need family planning as many as 304 people $(94.4 \%)$, there are four people married childbearing age women $(2.3 \%)$ who had more than four children, including in unmet need for family planning. When viewed from the $p$ value $p=0.085$ with $\alpha=0.05$, it can be concluded that there is no significant relationship between parity with the incidence of unmet need in family planning on married childbearing age women West Nusa Tenggara $(p>\alpha)$. Most of the educated middle married childbearing age women not unmet need as many as 174 people (54\%), and there were four people married childbearing age women $(2.3 \%)$ are not in school included in unmet need for family planning. When viewed from the $p$ value, $p=0.908$ with $\alpha=0.05$, it can be concluded that there is no significant relations between education and the incidence of unmet need in family planning on married childbearing age women West Nusa Tenggara $(\mathrm{p}>\alpha)$.
Based on table 2 known that married childbearing age women knowledge of one type of contraceptive that using contraceptives as many as 321 people (99.7\%) and 176 $(100 \%)$ did not know one of the methods contraceptives but do not use them. If the we view the value, when viewed from the $p$ value, $p=0.000$ with $\alpha=0.05$, it can be concluded that there is a significant relationship between knowledge and the incidence of unmet need in family planning on married childbearing age women of West Nusa Tenggara $(p<\alpha)$. The married childbearing age women who have access to as many as 207 people $(64.3 \%)$ use contraceptives tool and does not include unmet need, as well as 68 people $(38.6 \%)$ do not have access to family planning services included in unmet need for family planning. When viewed from the $\mathrm{p}$ value $p=0.518$ with $\alpha=0.05$, it can be concluded that there is no significant relationship between access to health care with the incidence of unmet need in family planning on marrying married childbearing age women of West Nusa Tenggara $(p>\alpha)$.

According to the table 2, married childbearing age women known that most living in rural areas, are not included in unmet need for family planning as many as 165 people $(51.2 \%)$, and married childbearing age women living in rural areas as 79 people $(44.9 \%)$ included in unmet need birth control. When viewed from the $p$ value $p=0.175$ with $\alpha=0.05$, it can be concluded that there is no significant relations between area of residence with the incidence of unmet need in family planning of married childbearing age women in West Nusa Tenggara $(p>\alpha)$. The married childbearing age women with very low incomes as much as 102 people $(31.7 \%)$ excluding unmet need, and as many as 19 people $(10.8 \%)$ with a rich category, included in unmet need for family planning. When viewed from the $\mathrm{p}$ value $\mathrm{p}=$ 0.774 with $\alpha=0.05$, it can be concluded that there is no significant relationship between the incidence of unmet need revenue by family planning on married childbearing age women in West Nusa Tenggara $(p>\alpha)$.

\section{DISCUSSION}

Age is very influential in regulating the number of children born 20-35 years of age period is the period of births for the required method efectiveness high enough, long periods of time (2-4 years) and reversible, and the period of over 35 years is a phase terminate the pregnancy so it takes contraceptives with higher criteria and do not add abnormalities or pre-existing disease[10]. According to National Population and Family Planning Board, the number of children in the family who had been born by sex, in living conditions or show signs of life as breathing, no heartbeat or pulse of the umbilical cord or muscular movements, and then explained what is meant by small family is a family the number of children at most two[11]. Poor economic conditions generally associated with various health problems encountered, the incidence of health problems due to incompetence and ignorance in dealing with the problems they face. Weak economic condition may affect the ability to buy, including ability to purchase contraceptive devices and drugs[12]. Education is a process of formation of the fundamental abilities, intellectual, emotional towards the universe and mankind. Education is a process in which these potentials (ability, capacity) are arranged in such a way and managed by humans to help others in pursuit of 
objectives[13]. The higher the person's level of education a person then the knowledge of unmet need will be better and interrelated, but in educational research does not affect the unmet need for family planning because it is influenced anxiety / fear on married childbearing age women family planning. The more anxious a person then that is used on oneself will not be achieved effectively. Level of education a person has a sense of anxiety that is different, so it does not have relations with unmet need for family planning[14]. Knowledge is the factor that facilitate or change behavior. To measure knowledge is by asking questions directly (interview) or with through written questions or questionnaires. Indicators of health knowledge is "high knowledge" about the respondents' health, or the percentage of respondents or community groups about health variables[15]. In this study are not consistent with other conducted research, found that from the results of 51 surveys conducted between 2006 and 2013 in Africa, Asia, and Latin America and the Caribbean shows that access to services that provide various methods for selecting, and information and counseling to help women choose and effectively using appropriate methods, can be important in helping women overcome barriers unmet need for contraception [16]. Found on female characteristics unmet need for family planning in urban and rural areas are not too different [17]. This is in line with research conducted in India, showed that the incidence of unmet need of family planning occur in urban and rural areas by $40 \%$ to $75 \%$. And the successful use of the highest birth rural located in the area of $92 \%$ [18]. This research is in line with a research, shows that of the 46 countries that have a low income and middle found the incidence of unmet need for family planning by $11.1 \%$ and $38.3 \%$ [19].

\section{CONCLUSION}

There was a significant correlation between the incidence of unmet need knowledge with family planning on married childbearing age women in West Nusa Tenggara $(p>\alpha)$. There needs to be some policies, in an effort to address factors related to the incidence of unmet need for family planning on married childbearing age women in West Nusa Tenggara province so that the target of National Population and Family Planning Board in Population, Family Planning, and Family Development Program can be achieved and meet national targets. It is expected that National Population and Family Planning Board in West Nusa Tenggara and some stakeholders to increase public knowledge about the married childbearing age women particular contraceptive method in West Nusa Tenggara. Also it is expected that National Population and Family Planning Board in West Nusa Tenggara to increase the role of the family, health providers or family planning field officer, in providing family planning services to the society especially woman of fertile age in West Nusa Tenggara.

\section{REFERENCES}

[1] "WHO | WHO joins call for renewed focus on family planning," WHO.

https://www.who.int/mediacentre/news/notes/2012/family_planning 20120711/en/ (accessed Jan. 31, 2020).
[2] "Jumlah Penduduk Indonesia Terbesar Ke Empat Dunia Setelah China, India Dan Amerika." /artikel/jumlah-penduduk-indonesiaterbesar-ke-empat-dunia-setelah-china-india-dan-amerika (accessed Jan. 31, 2020).

[3] "Survei Demografi dan Kesehatan Indonesia." http://sdki.bkkbn.go.id/?lang=id\&what=book (accessed Jan. 31, 2020).

[4] R. Yarsih, "Fakultas Kesehatan Masyarakat Universitas Sumatera Utara," p. 13, 2014

[5] U. Listyaningsih, S. Sumini, and S. Satiti, "UNMET NEED: KONSEP YANG MASIH PERLU DIPERDEBATKAN," Populasi, vol. 24, no. 1, pp. 72-90, Apr. 2016, doi: 10.22146/jp.23696.

[6] D. M. Aulia, "Bagian Epidemiologi Dan Biostatistika Kependudukan Fakultas Kesehatan Masyarakat Universitas Jember,” p. 94, 2019.

[7] S. Rismawati, "Unmet Need: Tantangan Program Keluarga Berencana Dalam Menghadapi Ledakan Penduduk Tahun 2030," 2014.

[8] J. Witjaksono, "Rencana Aksi Keluarga Berencana dan Kesehatan Reproduksi Tahun 2012-2014,” Jakarta: BKKBN, 2012.

[9] L. Sudarniasih, S. Maryuni, and A. Eka, "Implementasi Program Keluarga Berencana $(\mathrm{Kb})$ Di Puskesmas Rawat Jalan Wajok Hulu Kabupaten Mempawah," p. 17.

[10] L. Indahwati, L. R. Wati, and D. T. Wulandari, "Karakterstik Ibu (Usia, Paritas, Pendidikan, Pengalaman KB) Berhubungan dengan Pemilihan Metode Kontrasepsi," Journal of Issues in Midwifery, vol. 1, no. 2, pp. 9-18, Nov. 2017, doi: 10.21776/ub.JOIM.2017.001.02.2.

[11] "Family planning/Contraception." https://www.who.int/newsroom/fact-sheets/detail/family-planning-contraception (accessed Jan. $31,2020)$.

[12] "Kementerian PPN/Bappenas:: Rencana Aksi Nasional Program Penanggulangan Kemiskinan." https://www.bappenas.go.id/id/profilbappenas/unit-kerja/deputi-bidang-kemiskinan-ketenagakerjaan-danukm/direktorat-penanggulangan-kemiskinan/contents-direktoratpenanggulangan-kemiskinan/rencana-aksi-nasional-programpenanggulangan-kemiskinan/ (accessed Jan. 31, 2020).

[13] Kompasiana.com, "Pendidikan: Pembelajaran Bermodel," KOMPASIANA.

https://www.kompasiana.com/sri.martin/5723069e9a9373980761334 6/pendidikan-pembelajaran-bermodel (accessed Jan. 31, 2020).

[14] J. K. Wulifan, S. Brenner, A. Jahn, and M. De Allegri, "A scoping review on determinants of unmet need for family planning among women of reproductive age in low and middle income countries," BMC Womens Health, vol. 16, p. 2, Jan. 2016, doi: 10.1186/s12905015-0281-3.

[15] S. Notoatmodjo, "Metododologi Penelitian Kesehatan," Dec. 2019, Accessed: Jan. 31, 2020. [Online]. Available: http://r2kn.litbang.kemkes.go.id:8080/handle/123456789/77272.

[16] G. Sedgh and R. Hussain, "Reasons for contraceptive nonuse among women having unmet need for contraception in developing countries," Stud Fam Plann, vol. 45, no. 2, pp. 151-169, Jun. 2014, doi: $10.1111 / j .1728-4465.2014 .00382 . x$.

[17] I. Sinai, E. Omoluabi, A. Jimoh, and K. Jurczynska, "Unmet need for family planning and barriers to contraceptive use in Kaduna, Nigeria: culture, myths and perceptions," Culture, Health \& Sexuality, vol. 0, no. 0, pp. 1-16, Oct. 2019, doi: 10.1080/13691058.2019.1672894.

[18] J. R. New, N. Cahill, J. Stover, Y. P. Gupta, and L. Alkema, "Levels and trends in contraceptive prevalence, unmet need, and demand for family planning for 29 states and union territories in India: a modelling study using the Family Planning Estimation Tool," Lancet Glob Health, vol. 5, no. 3, pp. e350-e358, 2017, doi: 10.1016/S2214109X(17)30033-5

[19] C. Moreau, M. Shankar, S. Helleringer, and S. Becker, "Measuring unmet need for contraception as a point prevalence," BMJ Global Health, vol. 4, no. 4, Aug. 2019, doi: 10.1136/bmjgh-2019-001581. 